\title{
ENDEMIC PNEUMOCYSTIS CARINII PNEUMONIA IN SOUTH IRAN
}

\author{
BY \\ CORNELIUS POST*, WERNER DUTZ and IRAJ NASARIAN \\ From the Red Lion and Sun Society's Orphanage and Newborn Service, and the Department of Pathology, \\ Pahlavi University, Shiraz, Iran
}

(RECEIVED FOR PUBLICATION JUNE 17, 1963)

The entity of interstitial plasma cell pneumonia due to Pneumocystis carinii has received increasing attention during the past 10 years.

Extensive studies and reviews concerning this problem, its epidemiology and pathogenesis (Ahvenainen, 1957; Bachmann, 1954; Cahalane, 1962; Jírovec, 1960a and b; Müller and Vietor, 1957), its clinical course and picture (Berdnikoff, 1959; Dvořák and Jírovec, 1953; Gajdusek, 1957; Gerrard, 1958; Holland and Ward, 1962; White, Saxton and Dawson, 1961) as well as the radiological features (Falkenbach, Bachmann and O'Loughlin, 1961; Feinberg, Lester and Burke, 1961; White et al., 1961) have been published. The pathological and morphological changes are equally well defined by a thickening of the alveolar septa due to a plasmacellular infiltration as well as by a specific proteinrich exudate containing small foamy vacuoles with the protozoal bodies (Le Tan Vinh, Vialatte, Pellerin and Sinna, 1960; Vaněk and Jírovec, 1952; Stopka, Wunderlich and Carlson, 1957). These parasites have also been found in reticuloendothelial cells outside the lung (Zandanell, 1954). Histochemical studies (Ricken, 1958; Opferkuch and Ricken, 1959; Opferkuch, 1959; Nitschke and Heyn, 1960), ultra-thin sections (Timmel, 1960), and studies with the electron miscroscope (Pliess and Seifert, 1959; Timmel, 1960; Bommer, 1961) have confirmed the protozoal character of the parasite.

Although there were doubts whether Pneumocystis carinii was the aetiological agent in plasmacellular pneumonia, it now seems well accepted that it does cause this disease in debilitated children and occasionally in debilitated adults (Jírovec, 1959; Rubin and Zak, 1960; White et al., 1961). Primary cases in adults have been reported (Kaftori, Bassan, Gellei and Griffel, 1962; Lyons, Vinijchaikul and Hennigar, 1961). Pneumocystis was first seen by

* Present address: Children's Hospital Medical Centre, Boston, Mass., U.S.A.
Chagas in a monkey (1909a) while studying trypanosomiasis. The parasite has been described in many animals, and infections in dogs (Carini and Maciel, 1915; Akker and Goedbloed, 1960), rabbits (Blažek, 1960), and cats, mice, sheep, goats, monkeys and pigs have been reported (Pliess, 1953). Weller introduced experimental infections in rats by priming the animals with cortisone (Weller, 1955; Linhartová, 1958b). Since pneumocystosis is so widespread in animals, it is not surprising that infection is transmitted to humans, especially under crowded conditions where there is close association with domesticated animals and poor hygiene. The human host may play an important role too, in this respect, according to Pavlica (1962).

Pneumocystis carinii was first seen in a human lung in Brazil by Chagas (1909b), during his search for the life-cycle stages of Trypanosoma. However, the first clear description of the pathological anatomical picture and the association of pneumocystis with plasmacellular pneumonia was published during the last war in 1942 by Meer and Brug. Since then most of the cases described have been in Europe, especially in Germany and Czechoslovakia, where much attention was paid to this entity after the early studies by Vaněk and Jírovec (1952).

For the years 1951 to 1952 Dvořák and Jírovec (1953) reported 160 cases from Czechoslovakia alone, of which 86 were fatal and confirmed by autopsy. Recently it has become apparent that the disease has a world-wide distribution. After the initial description of this parasite from Brazil and Central Europe sporadic cases have been published from North America (Berdnikoff, 1959; Burke, Brown and Weed, 1962; Erchul, Williams and Meighan, 1962; Wilson, Crass and Garza, 1960). In the Near and Middle East one case has been described in Turkey (Unat, 1955) as well as several cases from Israel (Reif and Sandbank, 1959; Kaftori et al., 1962), and Ryan (1962) reported cases from New Guinea. 
TABLE 1

CAUSE OF DEATH OF 40 INFANTS IN FOUNDLING HOME AND NEWBORN NURSERY

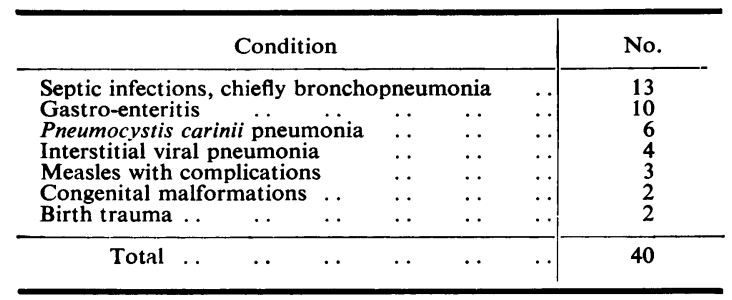

\section{Case Reports}

Between July 1961 and March 1963, clinical and epidemiological observations on the children in two nurseries in Shiraz in the South of Iran were made. During this time 168 infants and children were cared for in the orphanage nursery. All 40 children who died during this time were brought to autopsy. Table 1 shows the causes of death in these children: six died with Pneumocystis carinii infections.

Case 1. A baby girl, a foundling, was admitted in June 1961 at the age of 1 month; her admission weight was unknown. She was dystrophic and suffered from diarrhoea caused by food contamination. There was a steady slow weight loss. Four days before death she developed emesis, tachypnoea and cyanosis complicating her continuous diarrhoea. She died on July 26, 1961. Autopsy revealed a dystrophic child weighing 2,300 g. Development was retarded; there was spotty atelectasis of the lungs; no other pathological findings were noted. Histological examination showed a heavy plasmacellular and lymphocyte infiltration in the septa of the alveoli. Several areas showed complete collapse of the alveolar lumina, others contained typical eosinophilic proteinaceous exudate with foamy bubbly characteristics. Special stains confirmed the presence of pneumocysts in the small vacuoles of this exudate. No other remarkable findings were noted.

Case 2. A baby boy was born in our maternity clinic on August 7, 1961, weighing 1,300 g. and was admitted to the orphanage on October 10 , from the premature station of Nemazee Hospital, weighing 2,600 g. During the two months in the nursery the child did not gain any weight, suffered from repeated bouts of coughing and from diarrhoea. He was treated with tetracycline 11 days before death, but no improvement was obtained. A chest radiograph eight days before death showed infiltration of the right upper lobe. The child was transferred to hospital and died on December 15. The autopsy revealed interstitial plasma cell pneumonia with Pneumocystis carinii. In addition there were neutrophilic infiltrations of the alveoli with the classical picture of bronchopneumonic superinfection.

Case 3. A baby boy, a foundling, was admitted on February 3, 1962. He was estimated to be 1 week old, and weighed on admission 2,440 g. He died on May 9, 1962 , weighing $3,000 \mathrm{~g}$. During his stay he suffered from impetigo and systemic infections mainly of the upper respiratory tract. He fell seriously ill 10 days before death. The clinical course was marked by cough, cyanosis and lack of response to antibiotics. Autopsy revealed a fairly well-developed, malnourished baby boy, measuring $52 \mathrm{~cm}$. crown to heel. Both lungs were pale with occasional yellowish foci; they contained little air. The weight of the lungs was increased. The crosssection showed slight bulging and granularity of several lobular areas. Other findings were not unusual, except for a patent ductus arteriosus. Histological examination showed a diffuse thickening of the alveolar walls with infiltration by plasma cells and histiocytes. Several alveoli contained finely vacuolated granular exudate in the remaining spaces which, on high-power examination, revealed the typical pneumocysts.

Case 4. A baby girl, a foundling, was admitted on May 6, 1962, weighing 2,700 g. Her estimated age was 2 weeks. She died on July 8, 1962. During her stay in the orphanage the child suffered from several bouts of diarrhoea and gained only $400 \mathrm{~g}$.

Three days before death she developed pyrexia of $40^{\circ} \mathrm{C}$., vomiting and abdominal distension. On her last day there was tachypnoea and cyanosis with no response to high doses of penicillin and streptomycin. The autopsy showed a normal external situs. The lungs revealed focal atelectasis and showed some meaty-red areas. Microscopical examination revealed focal thickening of the septa with plasma cells and histiocytes as well as characteristic pneumocysts.

Case 5. A baby girl, a foundling, was admitted on July 12,1962 , weighing $1,900 \mathrm{~g}$. Her estimated age was 2 to 3 days. She died on November 6, 1962. On admission she was found to be microcephalic. The clinical course was marked by a poor sucking reflex and a continuous hypothermia. The total weight gain during the hospital stay was $600 \mathrm{~g}$. She fell ill 24 hours before death with tachypnoea, cyanosis and abdominal distension. Penicillin and streptomycin were given without noticeable effect. Autopsy showed microcephaly with severe malformation of the brain and external hydrocephalus. There was absence of the corpus callosum as well as two porencephalic areas in the temporal lobes. On gross examination the lungs revealed numerous areas of bluish depressed atelectasis of lobular pattern. Histological examination again revealed typical thickening of the septa. There was considerable alveolar infiltration by exudate and Pneumocystis carinii. Additionally there was severe focal atelectasis.

Case 6. A baby boy was born on December 17, 1962, at 9 a.m., in the Red Lion and Sun Newborn Service (Unit No. 13587), weighing 2,270 g. He died two days later at 4 p.m. The mother was a primipara, primigravida, of 15 years; delivery was normal, at full term, and without complications. The child was asphyctic and cyanotic at birth; 48 hours after delivery he was much improved, had good colour and started to suck. 


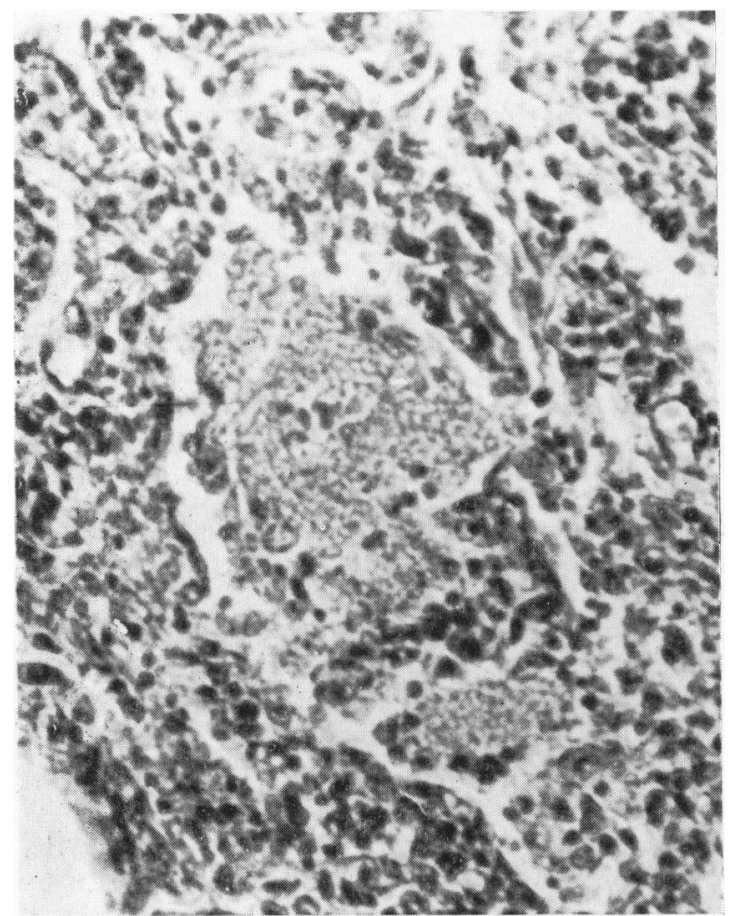

FIG. 1.-Congenital pneumocystis pneumonia: interstitial infiltrate of plasma cells. $(\times 440$.

Mongoloid idiocy was diagnosed clinically. Two hours before death, there was a very sudden onset of tachypnoea with cyanosis and rapid deterioration; he was treated with penicillin and streptomycin, but died despite oxygen and artificial respiration. At autopsy the lungs were very congested. There were numerous small petechial haemorrhages, marked atelectasis of lobular pattern, and other petechial haemorrhages over all the serous membranes. Sections of the lungs showed a variegated picture with areas of central irregular distension of alveoli, as seen in excessive artificial respiration, and some of the alveoli were filled with histiocytes. There was much diffuse thickening of all the septa leading to atelectasis (Fig. 1). These septa showed histiocytic proliferation as well as heavy lymphocytic and plasmacellular infiltration. Only in several small scattered alveoli was there foamy exudate with small cystic bubbly spaces showing the typical pneumocysts in the centre. Special stains confirmed this diagnosis (Fig. 2). Bacteriological cultures from the lung revealed a pure culture of Esch. coli.

\section{Discussion}

From the data presented above it seems that infection with Pneumocystis carinii constitutes an important problem in South Iran where it has never been described before. Our observations indicate that it is the third most frequent cause of death in a small but thoroughly investigated series of cases.

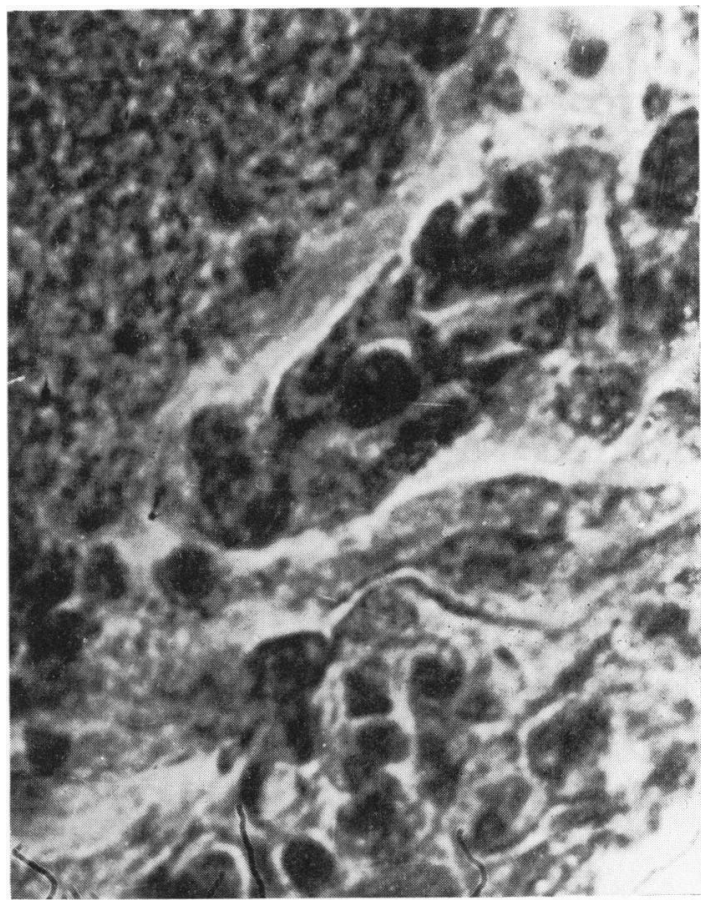

FIG. 2.-Congenital pneumocystis pneumonia: pneumocystis in alveolar space. $(\times 786$.

Although we realize that we cannot generalize on a series presented from among children in an institution, we would, nevertheless, like to point out that the orphanage in Shiraz constituted, at least at the end of the period, a more hygienic environment than the average home conditions in the poorer quarters of the city or the villages. The mortality figures are still more impressive if one realizes that during the initial period of observation an epidemic of food-borne staphylococcal enteritis was responsible for the deaths of six children in one month. With better facilities and personnel training, most of the other septic infections mentioned in Table 1 could have been prevented. Indeed all the children of the orphanage suffered at one time or another from similar septic conditions most of which responded to treatment.

Table 2 shows the shift during different seasons, and it is apparent that the usual seasonal incidence of gastro-enteritis and septic bronchial infections in summer and winter, respectively, persist continuously. This is partially beyond our control, since some of the foundlings suffer greatly from exposure on admission. However, the rate of death due to gastro-intestinal infections has been much reduced; indeed, considering the high summer 
TABLE 2

DISTRIBUTION OF DEATHS BY CAUSE AND SEASONAL INCIDENCE: AGE-GROUP 0-3 YEARS

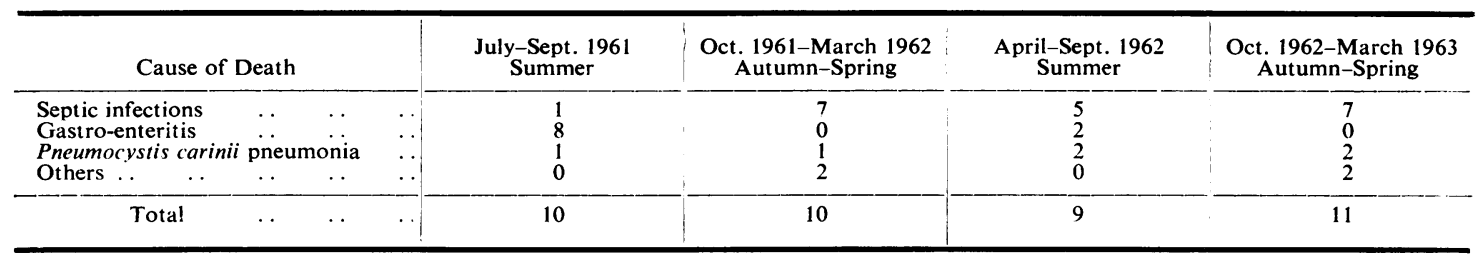

temperatures of up to $40^{\circ} \mathrm{C}$., we think we have reached the optimum possible under the prevailing circumstances. Pneumocystis infections, however, continued steadily throughout the entire period of observation.

There are two predisposing factors in our series of cases, namely prematurity and dystrophy. It has nearly always been shown that only those who are weakened by prolonged ill health are, with certain well-known exceptions, susceptible to the infection. Of our total of 40 deaths, 20 were premature and most of them were foundlings. Only five fatal cases showed good nutritional condition. It is probable that these children were left usually by unmarried and deserted mothers, who due to psychological and physical reasons have a tendency to premature delivery. These factors were greatly aggravated by the problems existing in the nurseries, where an insufficiently trained staff was unable to cope with anything but the most basic rules of antiseptic care. We would like to cite the example of one of our children, a full-term infant who showed a weight gain of $1,200 \mathrm{~g}$. in the first 10 months of life in the institution and gained $900 \mathrm{~g}$. in nine days on the same formula when cared for in a private foster home. This demonstrates beyond doubt that in the institution the psychological support for normal development was lacking. Our cases present a classic clinical picture and fit well with the descriptions given in published reports. All the children finally suffered from a rapid onset of cyanosis with tachypnoea and fever and were entirely resistant to antibacterial treatment. The method of diagnosing pneumocystosis from sputum smears was not attempted owing to limited facilities (Bachmann, 1954; Erchul et al., 1962; Stopka et al., 1957). The possibility of treating these cases with pamaquin or mepacrine hydrochloride, as suggested by Dvořák and Jírovec (1953), was unknown to the authors at that time and was not tried. At first it was suggested that this disease was invariably fatal, but since then several studies have been published that estimate the mortality rate differently and insist that healing is possible. Studies by Linhar- tová (1958a) showed several small and incidental foci in the lungs of seven children on whom autopsies were done, and who had no generalized plasmacellular reaction. Hamperl (1957b) described four clinically latent cases. Interesting also is the finding of pneumocystis in the smear preparations of two out of 203 random autopsies (Robinson, 1961): these were from two negroes, 30 years of age, from the same environment and social background in America. There is wide disparity of opinion as to mortality: while initially Vaněk and Jírovec thought that all infected children would die, other estimates vary from a mcrtality rate of $80 \%$ (Michailov, 1959), 50\% (Hamperl, 1957a), and between 20 and $40 \%$ (Cahalane, 1962). It is difficult to make definite statements based on published reports and our own observations.

Bachmann (1954) assumed that the incubation time was from 40 to 50 days; Gajdusek (1957) thought in terms of three to 11 weeks. It does seem that pneumocysts can be harboured in human lungs for some time without being clinically apparent (Hamperl, 1957b; Linhartová, 1958a), so that only a reduction in resistance of the host would make the disease manifest (Sheldon, 1962). Interesting in this respect is the description of several cases of pneumocystosis in children and adults with lowered or absent plasma gamma globulin levels (Burke, Krovetz and Good, 1961; Burke et al., 1962; Kaftori et al., 1962; McKay and Richardson, 1959; Russell, 1959). Malnourished and premature children tend to be especially sensitive in this respect. White et al. (1961) sum up several predisposing factors and report a few primary cases (loc. cit.).

As to the mode of transmission, we noticed that nearly all our cases were widely separated in time; only Cases 3 and 4 occurred two months apart and could be considered as cross-infections, stretching the incubation period somewhat. We can only assume that the infection either occurred during the time of exposure outside the nursery and that the disease became latent for some time, or that the disease was transmitted by human, animal or other carriers, directly or indirectly. In the orphanage 
we were not able to find any known vectors, e.g. mice. Cockroaches were abundant, and cats were frequently seen in the compound but did not get into the nursery. The personnel used to take their own nursing infants with them to work, but among these children there were no symptoms attributable to pneumocystis infection. Certainly the continuous overcrowding of the institution, which sometimes necessitated putting two or more children into one crib, must be counted as a contributing factor to the heavy involvement of our children in any of the contagious diseases recorded.

Case 6 is interesting in that it is the only child born in our maternity clinic, and not subsequently admitted to the orphanage, to develop pneumocystosis. This institution is in a different part of the city, but it is served by the same medical staff. This child died 39 days after Case 5, and this is the shortest interval between any of our cases. At death he was 2 days old and we consider that this was a congenital case, as far as we know the second to be recorded (Pavlica, 1962). If any carrier from the orphanage were to be responsible for this infection after birth, we should be dealing with an incredibly short incubation time. We did not elicit any significant data from the mother's history, though she had visited the prenatal clinics, situated in the same compound as the orphanage, and indirect contact with our last patient there is possible.

Müller and Vietor (1957) thought that, despite excellent nursing techniques, they had possible airborne cross-infections. It seems improbable that under the prevailing conditions in many countries and under the conditions of exposure of the children before admission to the foundlings' home, protective measures would be very successful. However, it is necessary to point out the urgency of this problem and to make sustained trials at prevention. Indeed, when it is clear to the staff and physicians working in this part of the world that pneumocystosis might be one of their more serious problems, it should be possible to direct attention to early diagnosis and therapeutic trial. The only hope we see is in sputum aspiration and staining, possibly also in the right interpretation of chest radiograms and in skin testing. Improved nutrition among the children as well as better isolation techniques should of course save more children. From the published material, weakness and ill health are serious contributions if not necessarily the decisive factors in this disorder. We think, therefore, that in areas where hygienic conditions are poor and where debilitated children are treated and kept in institutions, the pneumocystis rate will be greater than previously expected.
Similarly, among premature and malnourished children as well as among pregnant women in their homes, this disease must be regarded as a serious problem.

\section{Summary}

Six cases of Pneumocystis carinii pneumonia in South Iran are presented: all occurred among small infants in an institution; one was a congenital case. These constitute a high morbidity and mortality rate among the inmates over a period of 20 months; $12 \frac{1}{2} \%$ of all children who died during the observation period died of this pulmonary infection. It follows, therefore, that the problem of pneumocystis pneumonia in South Iran is a severe one.

\section{REFERENCES}

Ahvenainen, E. K. (1957). Interstitial plasma cell pneumonia. Pediat Clin $N$ Amer. 4, 203.

Akker, S van den and Goedbloed, E. (1960). Pneumonia caused by Pneumocystis carinii in a dog. Trop. geogr. Med., 12, 54 .

Bachmann, K. D. (1954). Zur Epidemiologie und Inkubation de frühkindlichen interstitiellen Pneumonie. $Z$. Kinderheilk., 74, 133.

Berdnikoff, G. (1959). Fourteen personal cases of Pneumocystis carinii pneumonia. Canad. med. Ass. J., 801.

Blažek, K. (1960). Die Pneumocystis Pneumonie beim Feldhasen. Zbl. allg. Path. path. Anat., 101, 484.

Bommer, W. (1961). Elektronenmikroskopische Untersuchungen an Pneumozystis carini aus menschlichen Lungen. Dtsch. med. Wschr., 86, 1309.

Burke, B. A., Krovetz, L. J. and Good, R. A. (1961). Occurrence of pneumocystis carinii pneumonia in children with agammaglobulinemia. Pediatrics, 28, 196.

Burke, E. C., Brown, A. L. Jr, and Weed, L. A. (1962) Pneumocystis carinii pneumonia: report of case in infant with hypogammaglobulinemia. Proc. Mayo Clin., 37, 129.

Cahalane, S. F. (1962). Pneumocystis carinii pneumonia: report of a case and review of the literature. J. Irish med. Ass., 50, 133

Carini, A. and Maciel, J. (1915). Ueber Pneumocystis Carini Zbl. Bakt., I. Abt. Orig., 77, 46.

Chagas, C. (1909a). Neue Trypanosomen Vorläufige Mitteilung Arch. Schiffs- u. Tropenhyg., 13, 120.

(1909b). Uber eine neue Trypanosomiasis des Menschen, ibid. 13,351 .

Dvớák, J. and Jírovec, O. (1953). Diagnostik und Therapie der durch Pneumocystis carinii verursachten parasitären atypischen Pneumonien bei Säuglingen. Acta paediat. (Uppsala), 42, 232.

Erchul, J. W., Williams, L. P. and Meighan, P. P. (1962). Pneumocystis carinii in hypopharyngeal material. New Engl. J. Med., $267,926$.

Falkenbach, K. H., Bachmann, K. D. and O'Loughlin, B. J. (1961). Pneumocystis carinii pneumonia. Amer. J. Roentgenol., 85, 706

Feinberg, S. B., Lester, R. G. and Burke, B. A. (1961). The roentgen findings in pneumocystis carinii pneumonia. Radiology, 76, 594 .

Gajdusek, D. C. (1957). Pneumocystis carinii-etiologic agent of interstitial plasma cell pneumonia of premature and young infants. Pediatrics, 19, 543.

Gerrard, J. W. (1958). Pneumocystis pneumonia. Pediat. Clin. $N$. Amer.. 5, 327

Hamperl, H. (1957a). Variants of pneumocystis pneumonia. J. Path. Bact., 74, 353.

(1957b). Uber heilende und abortive Pneumocystis-Pneumonie. Virchows Arch. path. Anat., 330, 325

Holland, P. D. J. and Ward, O. C. (1962). Pneumocystis carini pneumonia. Case reports. Irish J. med. Sci., No. 438, 258.

Jírovec, O. (1959). Uber die durch Pneumocystis carinii verursachte interstitielle Pneumonie der Säuglinge. J. Hyg. Epidem. (Praha), $3,1,28$.

(1960a). Toxoplasmose und Pneumozystose als Anthropozoonosen. Dtsch. Gesundh.-Wes., 15, 2383.

(1960b). Das Problem der Pneumocystis-Pneumonien vom parasitologischen Standpunkt. Mschr. Kinderheilk., 108, 136.

Kaftori, J. K., Bassan, H., Gellei, B. and Griffel, B. (1962). Pneumocystis carinii pneumonia in the adult. Report of a primary case. cystis carinii pneumo $109,438$.

Le Tan Vinh, Vialatte, J., Pellerin, J. and Sinna, H. T. (1960) La pneumonie à pneumocystis. Arch. franc. Pédiat., 17, 1149. 
Linhartová, A. (1958a). Herdförmige, klinisch latente Pneumozystis Pneumonie. Zbl. allg. Path. path. Anat., 98, 183.

- (1958b). Weitere Beiträge zur experimentellen Lungenpneumozystose. ibid., 98, 393.

Lyons, H. A., Vinijchaikul, K. and Hennigar, G. R. (1961). Pneumocystis carinii pneumonia unassociated with other disease. Clinical and pathological studies. Arch. intern. Med., 108, 929.

McKay, F.. and Richardson, J. (1959). Pneumocystis carinii pneumonia associated with hypogammaglobulinaemia. Lancet, 2, 713 .

Meer, G. van der and Brug, S L. (1942). Pneumocystis als parasiet bij den mensch. Ned. T. Geneesk., 86, 2066.

Mikhailov, G. (1959). Pneumocystis pneumonia (Russian text) Arkh. Pat., 21, No. 5, p. 46. Abstracted in Excerpta med. Arkh. Pat., 21, No. 5, p. 46. Abstr.
(Amst. VII, 14, 420 [No. 1945].

Müller, H. and Vietor, G. (1957). Klinisch-epidemiologische Beobachtungen bei der frühkindlichen interstitiellen plasmacellulären Pneumonie. $Z$. Kinderheilk., 79, 40.

Nitschke, A. and Heyn, K. (1960). Zur Frage des histologischen Nachweises von Pneumocysten bei der interstitiellen Pneumonie. Mschr. Kinderheilk., 108, 142.

Opferkuch, W. (1959). Zur Histochemie der Pneumocystis carinii. Virchows Arch. path. Anat., 332, 364.

- and Ricken, D. (1959). Die Fluorochromierung von Pneumocystis Carinii. ibid., 332, 132.

Pavlica, F. (1962). The first observation of congenital pneumocystic pneumonia in a fully developed stillborn child. Ann. paediat. (Basel), 198, 177.

Pliess, G. (1953). Die Pneumocystis Carinii und ihre Bedeutung bei der interstitiellen plasmacellulären Säuglingspneumonie. Frankfurt. Z. Path., 64, 185. and Seifert, K. (1959). Elektronenoptische Untersuchungen bei experimenteller Pneumocystose. Beitr. path. Anat., 120, 399.

Reif, A. and Sandbank, A. (1959). Pneumonia due to pneumocystis carinii. Harefuah, 57, 3 .
Ricken, D. (1958). Histologische Untersuchungen bei experimenteller Pneumocystis-Pneumonie. Virchows Arch. path. Anat., 331, 713 .

Robinson, J. J. (1961). Two cases of Pneumocystosis. Observation in 203 adult autopsies. Arch. Path., 71, 156.

Rubin, E. and Zak, F. G. (1960). Pneumocystis carinii pneumonia in the adult. New Engl. J. Med., 262, 1315 .

Russell, J. G. B. (1959). Pneumocystis pneumonia associated with agammaglobulinaemia. Arch. Dis. Childh., 34, 338.

Ryan, B. (1962). Pneumocystis carinii infection in Melanesian children. J. Pediat. 60, 914 .

Sheldon, W. H (1962). Pulmonary pneumocystis carinii infection. ibid., 61, 780 .

Stopka, E., Wunderlich, C. and Carlson, S. (1957). Morphologische und kulturelle Untersuchungen an Pneumocysten in Sputum und Lungenmaterial. $Z$. Kinderheilk., 79, 246

Timmel, H. (1960). Dünnschnittbefunde bei interstitieller Plasmocellulärer Säuglingspneumonie. Klin. Wschr., 38, 1003.

Unat, E. K. (1955). Turkiyeide ilk Pneumocystis carinii infeksiyonu. Türk Tip Cem. Mec., 21, 489.

Vaněk, J. and Jírovec, O. (1952). 'Interstitieller' Plasmazellenpneumonie der Frühgeborenen, verursacht durch Pneumocystis Carinii. Zbl. Bakt., I. Abt. Orig., 158, 120.

Weller, R. (1955). Zur Erzeugung von Pneumocystosen im Tierversuch. Z. Kinderheilk., 76, 366.

White, W. F., Saxton, H. M. and Dawson. I. M. P. (1961). Pneumocystis pneumonia. Report of three cases in adults and one in a child, with a discussion of the radiological appearances and predisposing factors. Brit. med. J., 2, 1327

Wilson, J. F., Crass, G. and Garza, B. L. (1960). Pneumocystis carinii pneumonia: report of a case and review of the recent literature. Pediatrics, 25, 468

Zandanell, E. (1954). Pneumozystisbefund ausserhalb der Lunge bei interstitieller plasmazellulärer Pneumonie der Säuglinge und Frühgeburten. Z Zl. allg. Path. path. Anat., 92, 74. 